Final version published in Family Relations

https://doi.org/10.1111/fare.12519

\title{
Head Start and Families' Recovery from Economic Recession: Policy Recommendations for COVID-19
}

\author{
William J. Scarborough, ${ }^{1}$ Caitlyn Collins, ${ }^{2}$ Leah Ruppanner, ${ }^{3}$ and Liana Christin Landivar ${ }^{4}$
}

\begin{abstract}
Objective: This article examines whether the availability of Head Start during the Great Recession mitigated the impact of this crisis on poverty rates among families with young children.

Background: The first two decades of the $21^{\text {st }}$ century have witnessed two major economic crises: the Great Recession and the COVID-19 pandemic. Poverty rates among families with young children grew substantially during the Great Recession. Families with young children are also more vulnerable to instability during the COVID-19 pandemic as job losses have been steeper and childcare availability has been significantly curtailed. Programs like Head Start that support at-risk families may mitigate such negative consequences.

Method: This study uses data from the American Community Survey from 2006 through 2016 and state-level data on Head Start availability from Program Information Reports. Growth curve modeling is used to examine how the availability of Head Start predicted poverty growth during the Great Recession and the speed of recovery post-recession.

Results: States with higher rates of Head Start enrollment had a smaller increase in family poverty during the Great Recession and a more stable recovery than states with lower Head Start enrollment.

Conclusions: These findings suggest that greater access to Head Start programs prevented many families from falling into poverty and helped others exit poverty during the Great Recession. Implications: The findings provide clear, evidence-based policy recommendations. Increased federal funding for Head Start is needed to support families during a COVID-19 recession. States should supplement these allocations to expand Head Start enrollment for all eligible families.
\end{abstract}

Keywords: economic recession, childcare, Head Start, poverty, families, policy, COVID-19

\footnotetext{
${ }^{1}$ University of North Texas, William.Scarborough@unt.edu

${ }^{2}$ Washington University in St. Louis, c.collins@wustl.edu

${ }^{3}$ University of Melbourne, Leah.Ruppanner@unimelb.edu.au

${ }^{4}$ Maryland Population Research Center, liana.c.landivar@gmail.com
} 


\section{Head Start and Families' Recovery from Economic Recession: Policy Recommendations for COVID-19}

The COVID-19 pandemic is the greatest challenge the world has faced this millennium. Millions have been infected with the virus and hundreds of thousands have died (World Health Organization, 2020). Beyond these unprecedented health consequences, the pandemic has upended national economies and dramatically impacted daily life. In the U.S., high rates of virus transmission have coincided with one of the fastest and most severe economic downturns in history as businesses closed or reduced operations across the country. In a period of only three weeks from March to April, 2020, over 16 million people filed unemployment insurance claims, more than double the number of claims made during the peak two years of the Great Recession of 2007-2009 (Cohen \& Hsu, 2020). Recent trends have shown sustained levels of high unemployment well into the third quarter of 2020, with many projections forecasting the onset of a long-lasting global recession (Fernandes, 2020; McKibbin \& Fernando, 2020). Not only are many families facing extreme economic precarity, but school and childcare closings during the pandemic have removed major sources of support on which families rely. These challenging conditions require effective policy solutions to support families and advance economic recovery following the pandemic.

In this study, we contribute evidence-based policy recommendations to support families during and after the COVID-19 related recession. To do this, we seek lessons from the last economic recession to examine how variation between states in families' access to Head Start was associated with economic recovery following the 2007-2009 Great Recession. Head Start is a means-tested school readiness program that offers free childcare and comprehensive family support services for eligible children in families with incomes below established thresholds. In times of economic recession, programs like Head Start may provide a vital resource for families 
who lack childcare support as they seek employment or return to work. Yet, the availability of Head Start varies widely depending on families' state of residence. Community agencies have discretion in allocating federal funds and state governments may supplement funding to expand Head Start availability and services (Barnett \& Friedman-Krauss, 2016). Consequently, there are stark differences in rates of Head Start enrollment between states. Leveraging this variation, we illustrate the value of this federal program by showing that family poverty rates increased less and recovered faster in states with higher Head Start enrollment during the 2007-2009 recession.

Our results provide empirical evidence that Head Start can play a vital role in keeping families afloat during periods of economic crisis. As we face new challenges stemming from the COVID-19 pandemic, we urge policymakers to heed this evidence and designate funding to expand Head Start. The program has established processes and infrastructure making it suitable for expansion through federal, state, and community funding. Our findings suggest that increased Head Start funding will hasten post-pandemic economic recovery as it did when Head Start funding was increased under the American Recovery and Reinvestment Act during the last recession in 2009 (Office of Head Start 2010). As more families become economically vulnerable and childcare centers close, we provide evidence from the Great Recession to show that ensuring Head Start spaces for all eligible children and broadening eligibility guidelines will play a key role in keeping vulnerable families out of poverty.

\section{ChildCARe AND FAMily Support IN THE United STATES}

The U.S. government plays a much smaller role in childcare provision than in many European nations (Collins, 2019). In the absence of public support, most families must turn to the market, relatives, friends, and sometimes all three to provide care. Others reduce their employment or leave the labor force when faced with expensive childcare costs before children start public 
school at ages five or six (Ruppanner, Moller, \& Sayer, 2019). Labor force exits due to childcare are more common among mothers than fathers because they remain primarily responsible for the care of children (Scarborough, Sin, \& Risman, 2019). Recent research shows this is particularly true during the COVID-19 pandemic, as the increased caregiving demands associated with childcare center closures and homeschooling has led to mothers exiting the labor force at a rate three times that of fathers (Heggeness and Fields, 2020; see also Landivar et al., 2020). This places working- and middle-class families in a double bind. Wage stagnation since the 1970s has meant that two incomes are increasingly necessary to fulfill the rising cost of basic needs (Wilmers, 2018), but expensive and difficult to access childcare means that many families must choose between taking on a major monthly expense or substantially reducing their household income as one parent, usually the mother, stays home to provide care from birth to school age (Landivar, 2017; Ruppanner, 2020). Single-parent families are especially susceptible to poverty given these demands (Misra, Moller, \& Budig, 2007), which explains their overrepresentation below the poverty line (U.S. Census Bureau, 2018).

Although the U.S. lacks a comprehensive public childcare system, some programs do exist to support eligible families. These include Child Care and Development Block Grants (CCDBG) childcare subsidies, state-funded pre-kindergarten programs, and Head Start. CCDBG subsidies provide financial support for low-income families to pay for childcare in order to increase children's school readiness and allow parents to work or advance their educational and training qualifications. However, less than a quarter of eligible families receive subsidies (Government Accountability Office, 2019), and these provisions rarely cover all childcare expenses: the average co-payment for subsidy recipients is $7 \%$ of family income (U.S. Department of Health and Human Services, 2019). State-funded pre-K programs are more 
accessible, but still enroll only about a third of four-year-olds and less than $10 \%$ of three-yearolds (Friedman-Krauss et al., 2020). Unlike CCDBG subsidies or Head Start, pre-K funding is not tied to sustaining federal sources. Consequently, 19 U.S. states currently offer no statefunded pre-K programs.

Although CCDBG subsidies and state-funded pre-K provide major support to families, we focus on Head Start as the oldest and largest federally funded early childhood development program. Head Start is a categorical grant program administered by the Office of Head Start in the Department of Health and Human Services. Federal grants, sometimes combined with supplemental state funding, are allocated to local agencies administering Head Start programs in each state. Head Start programs serve children under the age of three through Early Head Start, and preschool centers focus on children ages three and four. Enrollment is free for eligible children who must be ages five or under, live in a family with income below the poverty line, receive other types of income-based public assistance, be homeless, or be in foster care (Hofferth, 1994; Office of Head Start, 2019). Head Start focuses on school readiness, but it also provides a range of other family support services related to housing, health and wellbeing, financial security, and continuing education (Office of Head Start, 2019). As a result, Head Start offers a more comprehensive system of support for families in need than CCDBG subsidies or pre-K programs. Annually serving nearly one million children, Head Start operates in all 50 states and the District of Columbia (Barnett \& Friedman-Krauss, 2016). With an established infrastructure, a holistic focus on families experiencing economic hardship, and regular budget allocation from Congress, Head Start constitutes a potentially effective program to support families through periods of economic recession. 
Despite being the largest federally funded childhood development program, Head Start funding is not highly responsive to changes in demand. Consequently, a significant share of eligible families remain without a slot due to limited funding. Nationally, this means only $9 \%$ of three-year-olds and $12 \%$ of four-year-olds - or about $40 \%$ of all preschoolers living in families below the poverty line - are enrolled in Head Start (Chaudry et al., 2017). Of course, families who cannot access Head Start for childcare likely turn to alternative options from friends, family and the market. Federal funding for Head Start remains well below the established demand for these programs. Head Start funding is allocated federally, but states can bolster these funds and community agencies have significant discretion in how they are used. Different states give primacy to enrollment, teacher salaries, or curricula. As a result, Head Start enrollment varies dramatically across states (Barnett \& Friedman-Krauss, 2016). In North Dakota, for example, $100 \%$ of eligible families are enrolled in Head Start, whereas only $22 \%$ are enrolled in Nevada (see Figure 1). Variation in the availability of Head Start means that eligible families face different institutional constraints in accessing this federal provision depending on where they live. Families in places like Ohio (55\% of eligible families enrolled) have far more access to free childcare through Head Start than those living in neighboring Indiana (34\%). 
Figure 1. Availability of Head StaRT IN 2009-2011 By State.

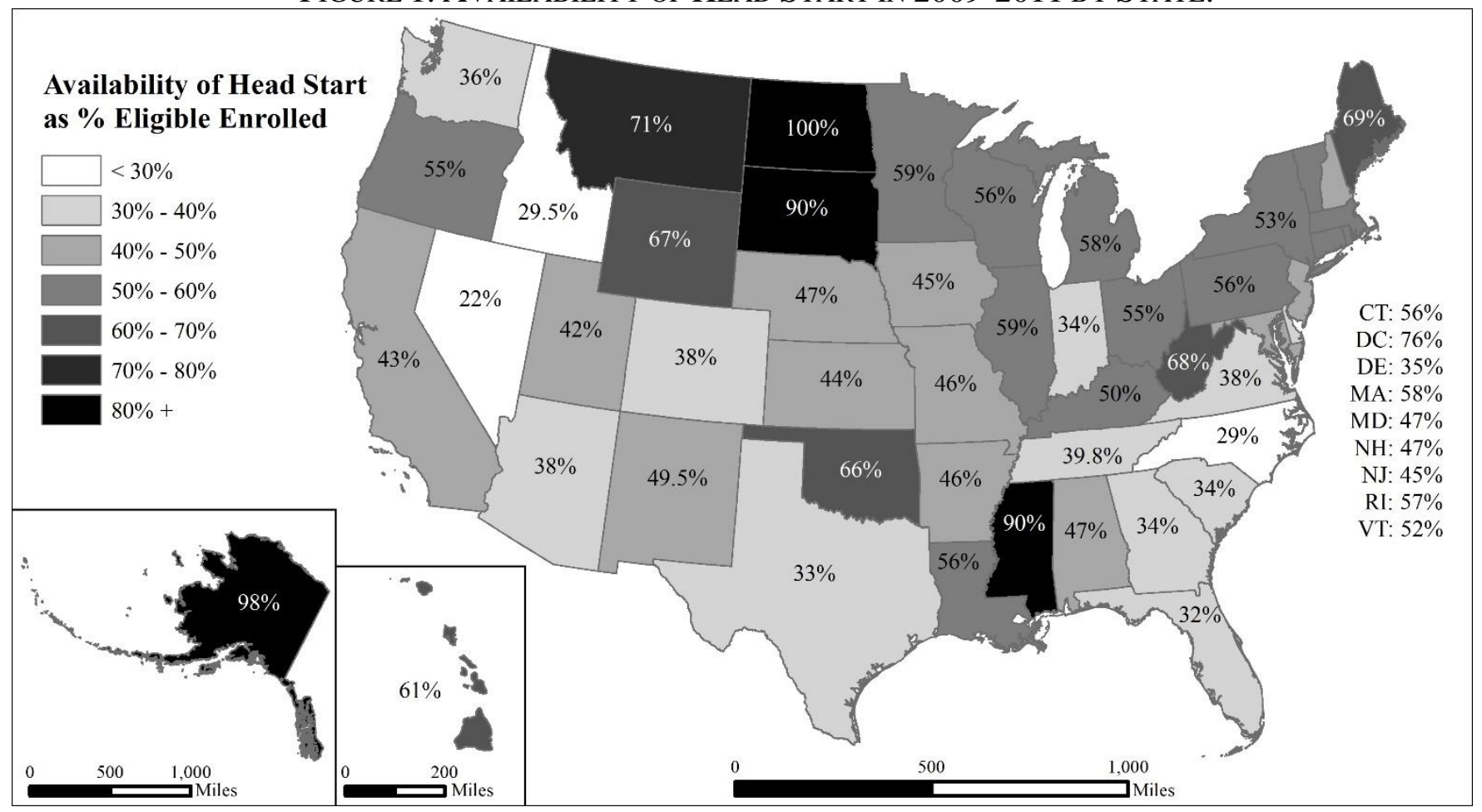

Source: Head Start Program Information Reports, years 2009-2011.

These differences may be particularly consequential during times of economic recession.

We conceptualize these relationships through a capabilities perspective, which posits that institutional constraints limit an individual's autonomy and self-actualization (Sen, 1993; see also Hobson 2018). By theorizing individuals as embedded in institutional structures that both constrain and create opportunities (capabilities), we can understand larger demographic patterns including, here, how state-to-state differences in access to Head Start may structure family poverty and economic recovery. Head Start is meant to improve capability by equalizing access to high-quality childcare to improve school readiness and close income-based educational gaps. However, current provisions are insufficient to meet demand, leading to variation in spaces across states. In states with few available openings for Head Start enrollment, parents who experience job loss may need to stay home to provide childcare-a diminished capability 
bounded by an institutional constraint. This poses challenges for those seeking new employment and pushes vulnerable families further into poverty.

Those who lose their jobs may not only fall into poverty during recession periods but, in the absence of childcare supports, they may remain in poverty longer than those living in states where Head Start is more readily available. Consequently, states with lower enrollment in Head Start may experience longer and more sustained economic recessions. By contrast, states with more accessible Head Start programs may see quicker rebounds out of poverty for vulnerable families, which we conceptualize as a capabilities-enhancing institutional context for parents. Parents in states where eligible children may be readily enrolled in Head Start have more opportunity to obtain employment and will be less likely to be priced out of work as a result of expensive childcare. They are also less likely to leave a job due to childcare problems - a common cause of labor force exits (Mathur \& McCloskey, 2014). Beyond childcare and childhood development, these families also receive other services through Head Start programs that support housing stability, children's health and wellbeing, parents' continuing education, and financial security. Considering these benefits, we theorize Head Start as a central institutional mechanism to alleviate challenges facing working families and, by extension, state economies.

\section{HeAd Start AND ECONOMIC WELlbEIng: EVIDENCE FROM THE GREAT RECESSION}

To test capabilities arguments that programs such as Head Start may support families' recovery from economic hardship, we explore the relationship between Head Start availability and rates of family poverty from 2006 through 2016 which captures the period before, during, and after the 2007-2009 Great Recession. Unlike CCDBG subsidies and state-funded pre-K programs, Head Start programs offer additional services to support families in poverty and are, therefore, more 
directly suited to address the challenges families face during periods of economic downturn. We also focus on Head Start because it is the longest running federal program for early childhood development and thus has existing infrastructure for expansion. Indeed, the federal government provided an additional $\$ 2.1$ billion in federal funding through the American Recovery and Reinvestment Act of 2009 to increase Head Start enrollment during the Great Recession (Office of Head Start, 2010). Thus, there is precedent for expanding federal funding and enrollment in Head Start during times of economic uncertainty. We explore whether Head Start was effective in buffering families from poverty by examining whether variation in its availability between states predicted growth in family poverty during the Great Recession as well as changes in rates of family poverty during the post-recession recovery years.

Our study speaks to a core theoretical argument from the capabilities perspective: governments are integral in alleviating institutional barriers to individual capabilities. Here, we argue that access to Head Start programs are integral to helping families out of poverty and, as a result, accelerating economic recovery from periods of recession. We investigate one central research question: Did the state-level availability of Head Start at the height of the last economic recession influence both the rise of family poverty during the recession and its decline in the post-recession recovery years?

Our expected relationships are hypothesized below:

\section{Poverty Vulnerability:}

H1: States with a higher percentage of eligible children enrolled in Head Start will have less poverty growth during the Great Recession than states where Head Start was less accessible. Economic Recovery 
$\mathrm{H} 2$ : States with a higher percentage of eligible children enrolled in Head Start will have quicker economic recoveries following the Great Recession than states where Head Start was less accessible.

\section{MeTHOD}

Data

We use data from the American Community Survey (ACS) for years 2006 through 2016 (Ruggles et al., 2020), spanning the period of time before, during, and after the Great Recession. The U.S. Census Bureau conducts the ongoing ACS and currently collects socio-demographic information from approximately 3.5 million households annually (U.S. Census Bureau, 2020). It is the single most comprehensive source of information on the U.S. population. These data provide adequate sampling of the U.S. to support robust state-to-state comparisons for detailed groups. In the absence of an existing dataset of families enrolled in Head Start over an extended period of time and across all U.S. states, the ACS constitutes the highest quality data to address our research questions. Here, we include families with children under age five because they are in most need of childcare and development support. This resulted in a sample of 1,540,486 families across 50 states and Washington, D.C. (between 132,000 and 146,000 families per year). With this sample of families, we constructed a panel of state-years which we used to analyze the relationship between state-level Head Start enrollment and poverty rates for families with young children. Our data consist of 51 states (including Washington, D.C.) across 11 years for a total sample of 561 state-years.

\section{Analytic Approach}

We use growth-curve models to examine how changes in the poverty rate for families with young children from 2006 through 2016 vary between states as a function of Head Start 
enrollment. Growth-curves are ideal for testing the effects of state-level childcare support on long-term rates of family poverty because this approach specifically focuses on differences between units in trajectories of change over time, here, changes in the trajectory of family poverty rates (Raudenbush \& Bryk, 2002). In our application, we predict the state-year poverty rate for families with young children using a regression model that allows trends to vary by state:

$$
y_{t s}=\beta_{1}+\beta_{2} w_{t s}+\beta_{3} w_{t s}^{2}+\gamma_{1 s}+\gamma_{2 s} w_{t s}+\gamma_{3 s} w_{t s}^{2}+\varepsilon_{t s}
$$

Here, $y_{t s}$ is the state-year percentage of families with young children whose total income in the survey year is below the federal poverty line, as determined by the U.S. Department of Health and Human Services (2020). This outcome is modeled as a function of yearly change from 2006 through 2016, $w_{t s}$, and year-squared, $w^{2}{ }_{t s}$ to account for non-linearity in these patterns. Together, these terms describe the rise in family poverty during the recession $\left(w_{t s}\right)$ and its subsequent decline during the period of post-recession economic recovery $\left(w^{2}{ }_{t s}\right)$. Capturing between-state differences, $\gamma_{1 s}$ represents state-variation in the intercept predicting baseline differences between states in family poverty rates. Differences in trajectories are represented by $\gamma_{2 s}$ and $\gamma_{3 s}$ which predict state-variation in poverty trends over time. By specifying trend coefficients to vary, we focus our attention on differences between states in the extent that family poverty rates changed between 2006 and 2016.

To test our hypothesis related to the protective effects of Head Start, we added an interaction between the trend terms in Equation 1 and a variable measuring the percentage of eligible children enrolled in Head Start around the height of the recession in 2009.

$$
y_{t s}=\beta_{1}+\beta_{2} w_{t s}+\beta_{3} w_{t s}^{2}+\beta_{4} H_{s}+\beta_{5} H_{s} w_{t s}+\beta_{6} H_{s} w_{t s}^{2}+\gamma_{1 s}+\gamma_{2 s} w_{t s}+\gamma_{3 s} w_{t s}^{2}+\varepsilon_{t s}
$$


$\mathrm{H}_{s}$ measures the percentage of eligible three- and four-year-olds enrolled in Head Start for each state averaged between 2009 and 2011. Data for this measure are from the Head Start Program Information Reports compiled by diversitydatakids.org at the Heller School for Social Policy and Management at Brandeis University. We focus on Head Start enrollment during the years 2009 through 2011 because most recession indicators reached their peak in these years. Unemployment, for example, peaked at 10\% in October 2009 and remained above 9\% through September of 2011 (Bureau of Labor Statistics, 2020a). Examining the role of Head Start enrollment during these years allows us to specifically examine whether this family support program mitigated against an increase in poverty. Interacting Head Start availability with both year and year-squared, we are able to test whether levels of Head Start enrollment were associated with slower growth in family poverty rates during the recession (year, $\beta_{5} H_{s} w_{t s}$ ), as well as its relationship to rates of recovery post-recession (year-squared, $H_{s} w^{2}{ }_{t s}$ ).

We also include a number of control variables in our models. First, to account for additional programs serving families' childcare needs, we control for the percentage of eligible families receiving CCDBG subsidies and the percentage of three- and four-year-olds enrolled in state-funded pre-K. We use average rates of subsidy receipt and pre-K enrollment from 2009 through 2011 to correspond to our measure of Head Start enrollment and account for potential spuriousness. Data on subsidy receipt were obtained from the U.S. Department of Health and Human Services (2014) and data on pre-K enrollment come from the National Institute for Early Education Research (Barnett et al., 2011). Interactions between these two covariates with year and year-squared were conducted, but are not included in our results because they were nonsignificant and did not alter substantive findings related to our hypotheses. Controlling for variation in the degree to which states were affected by the recession, our models also include 
controls for baseline rates of unemployment in 2006 as well as change in unemployment rates from the beginning of the recession in 2007 to the end in 2009. Four additional covariates account for state socioeconomic characteristics. The share of workers employed in manufacturing, one of the hardest-hit industries in the recession, is used to control for industry conditions within each state across years of data. Immigrant density is measured as the percentage of the state population that is foreign born. Racial composition is measured as the percentage of residents who are white. And average levels of human capital are controlled for with the share of state residents with a college degree.

Although Equations 1 and 2 include varying intercepts and slopes that account for some unobserved heterogeneity between states, the effects of Head Start on poverty trajectories could be confounded by additional, unobserved state-level characteristics. To account for this, we apply Equation 2 to a counterfactual sample of families without young children $(n=18,896,158)$. Although Head Start may indirectly benefit families without young children through supporting state economies as a whole, the effects should be less pronounced for these families than those with young children who more directly benefit from Head Start childcare provisions. Testing for these differences allows us to identify whether the observed relationship between Head Start and poverty trajectories are spurious, since unobserved confounders would apply equally to families with young children and those without, whereas the primary mechanism of childcare and child development provisions provided by Head Start should be felt the most among families with young children.

We present our results in two sections. First, we report descriptive trends in Head Start enrollment and state-level poverty rates for families with young children from 2006 through 
2016. Second, we present the results of our growth curve models designed to test the relationship of Head Start enrollment to changes in family poverty rates.

\section{RESULTS}

\section{Descriptives}

Family poverty rates rose during and immediately following the recession. National trends illustrated in Figure 2a indicate that about 21\% of families with young children were living below the federal poverty line in 2006 . In 2009 , this number increased to $23.4 \%$, and continued to grow until 2011 when it peaked at $25.6 \%$ where it remained through 2012. At its worst, over one-quarter of U.S. families with young children were living in poverty. Since 2012, however, there has been a steady decline in the rate of poverty for families with young children. By 2016, $21.5 \%$ of families were in poverty, slightly higher than the pre-recession share.

National trends in rates of family poverty remain consistent when using a higher poverty threshold: families living below $150 \%$ of the federal poverty line (Figure $2 \mathrm{~b}$ ). Again, there was an increase in families living in or on the brink of poverty during the recession years, continuing through 2011 and 2012 when nearly 38\% of families with young children were living below $150 \%$ of the poverty threshold. Following 2012 , the share of families living below $150 \%$ of the poverty line fell through 2016 . Henceforth, we direct our focus to the rate of families living below the poverty line, but all analyses were also conducted using a threshold of $150 \%$ of the poverty line and substantive findings remain consistent. 
Figure 2. FAMILIES With Young ChILDREN IN POVERTY.

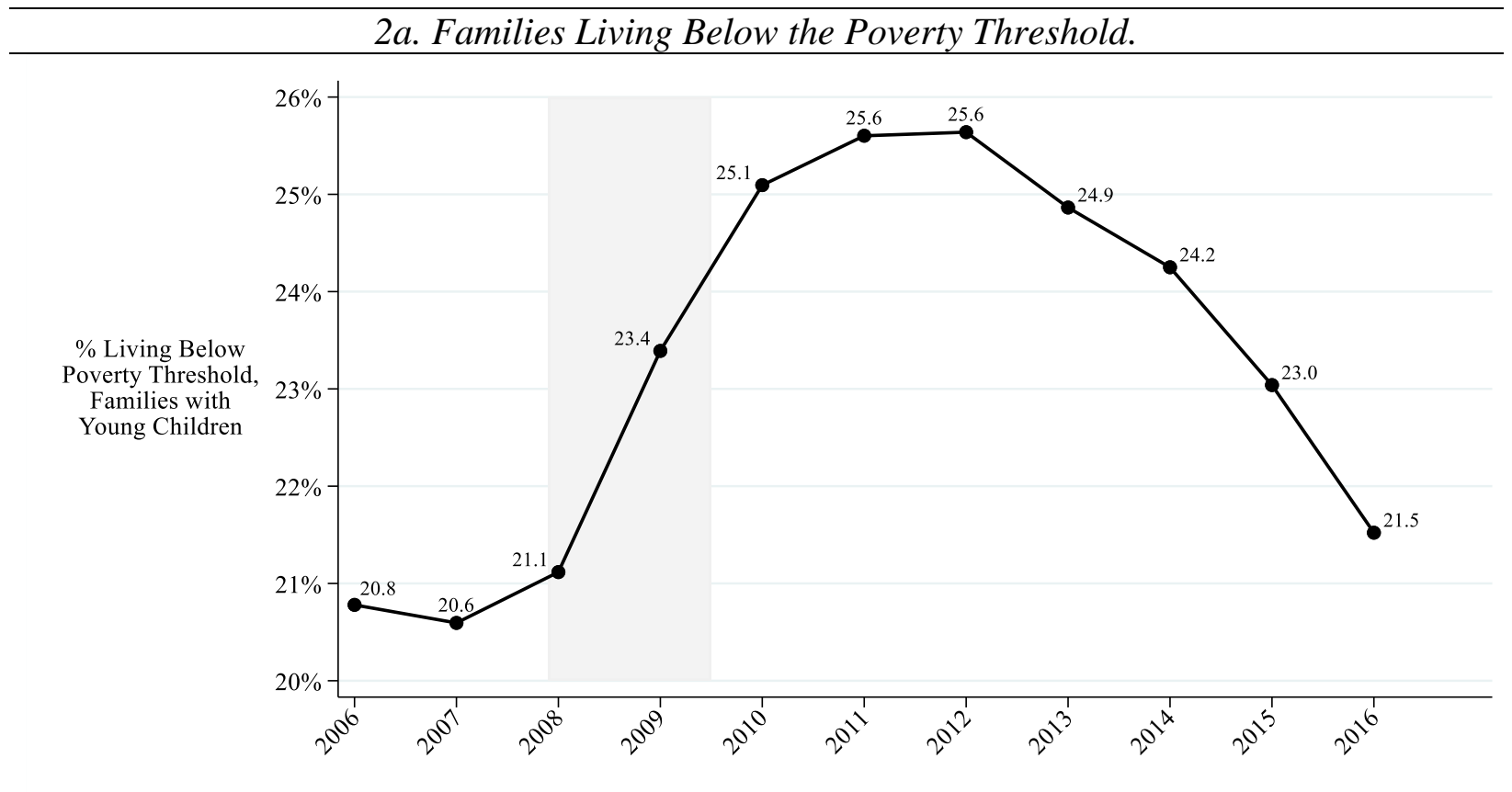

\section{2b. Families Living Below 150\% of the Poverty Threshold.}

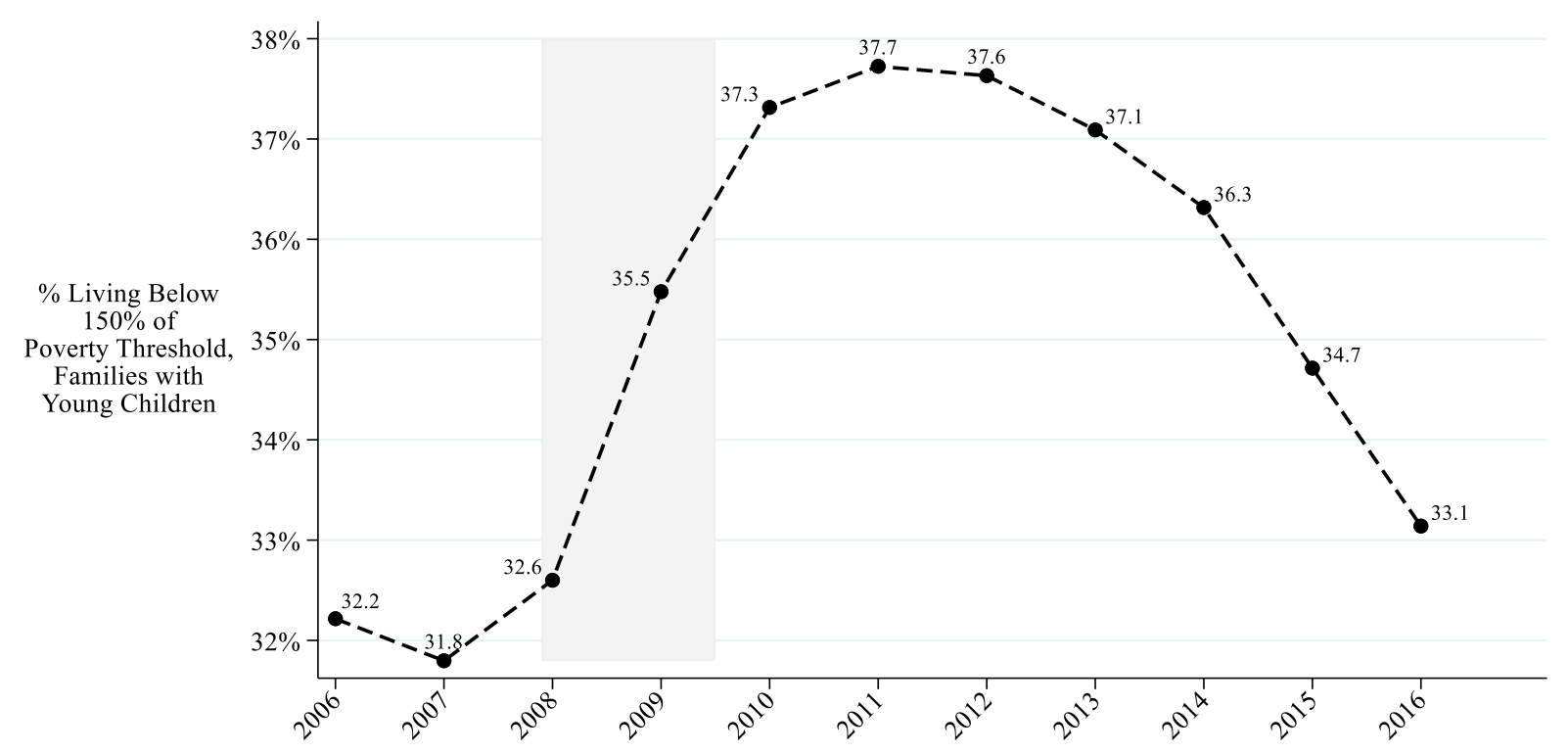

Note: Shaded area represents recession period from December 2007 through June 2009. Only families with at least one child under age 5 are included.

Source: American Community Survey, 2006 through 2016. 
Changes in family poverty rates from 2006 through 2016 varied widely between states. As illustrated in Figure 3, nearly all states experienced an increase in family poverty during the recession years. However, the extent of that increase, and the rate of subsequent recovery, differed from state to state. Oklahoma, for example, had a slight increase in family poverty followed by a precipitous decline. Nevada, in contrast, had a major increase in family poverty during the recession - a change that it had yet to fully recover from in 2016, when family poverty rates remained higher than they were in pre-recession years. Colorado, meanwhile, witnessed growth in family poverty during the recession, but by 2016 it had lower rates of poverty than it had in 2006.

Descriptive trends illustrated in Figures 2 and 3 highlight both the tremendous consequences of the Great Recession on family poverty and the variation in these effects across states. Considering the role that childcare support plays in families' economic participation and the variation in the extent to which programs like Head Start are available across states, it is possible that the accessibility of Head Start during the recession years played a role in shaping how severely the recession impacted rates of family poverty. To test this relationship, we now turn to the results of the growth curve models. 
Figure 3. FAMily POVERTy RATES By State.
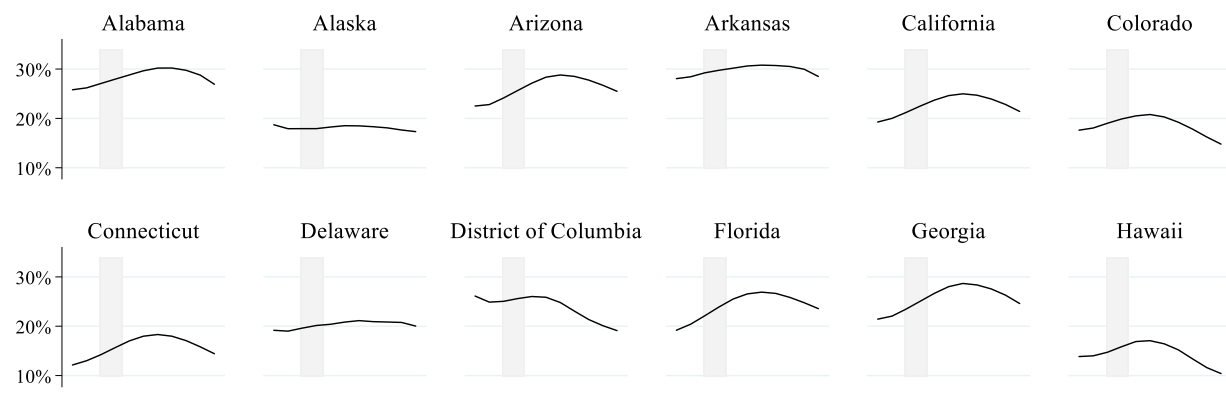

Delaware District of Columbia
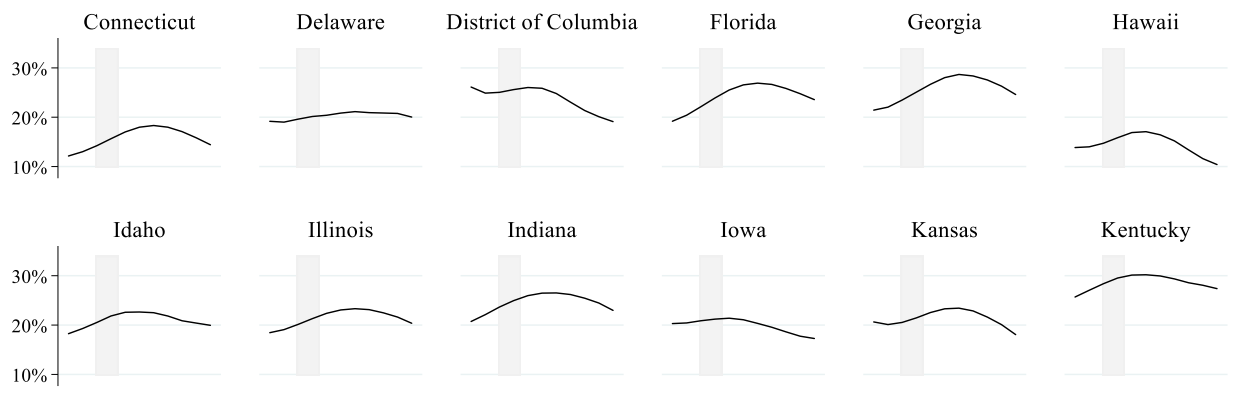

Illinois

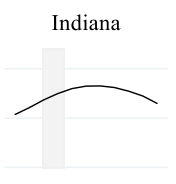

Iowa

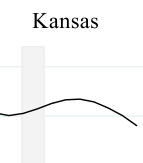

Kentucky
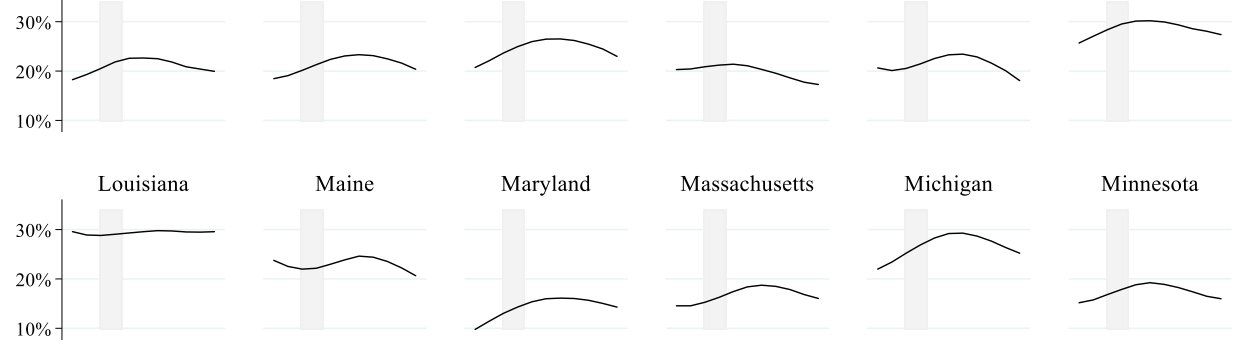

$\%$ in Poverty,

Families with

Young Children
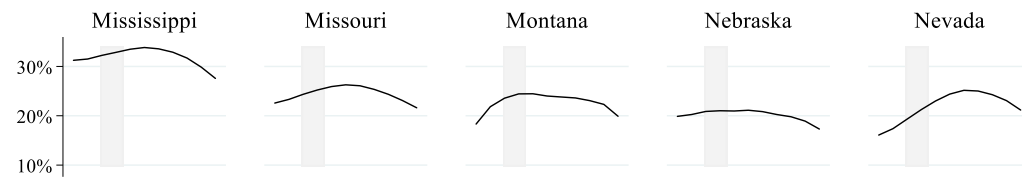

Minnesota
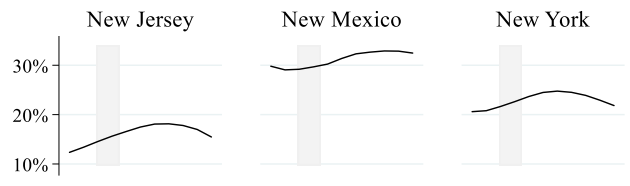

North Carolina

North Dakota
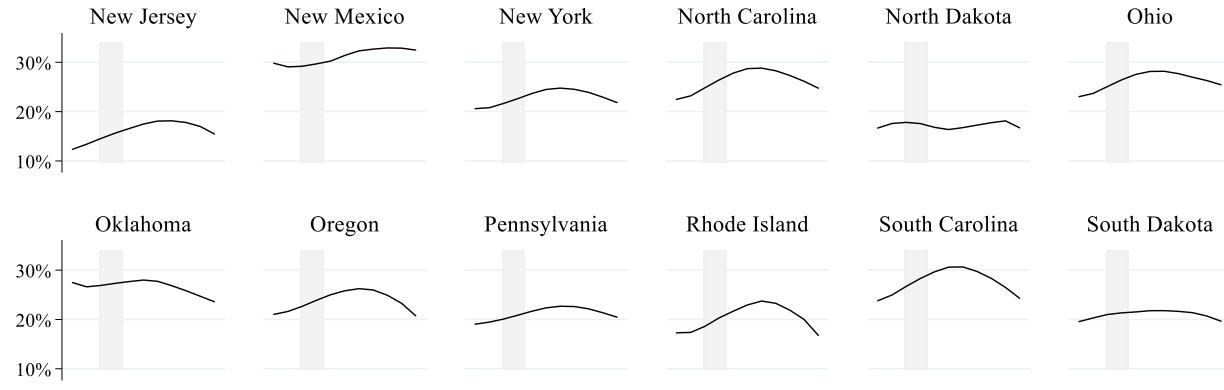

Pennsylvania

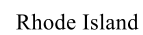

South Carolina

South Dakota
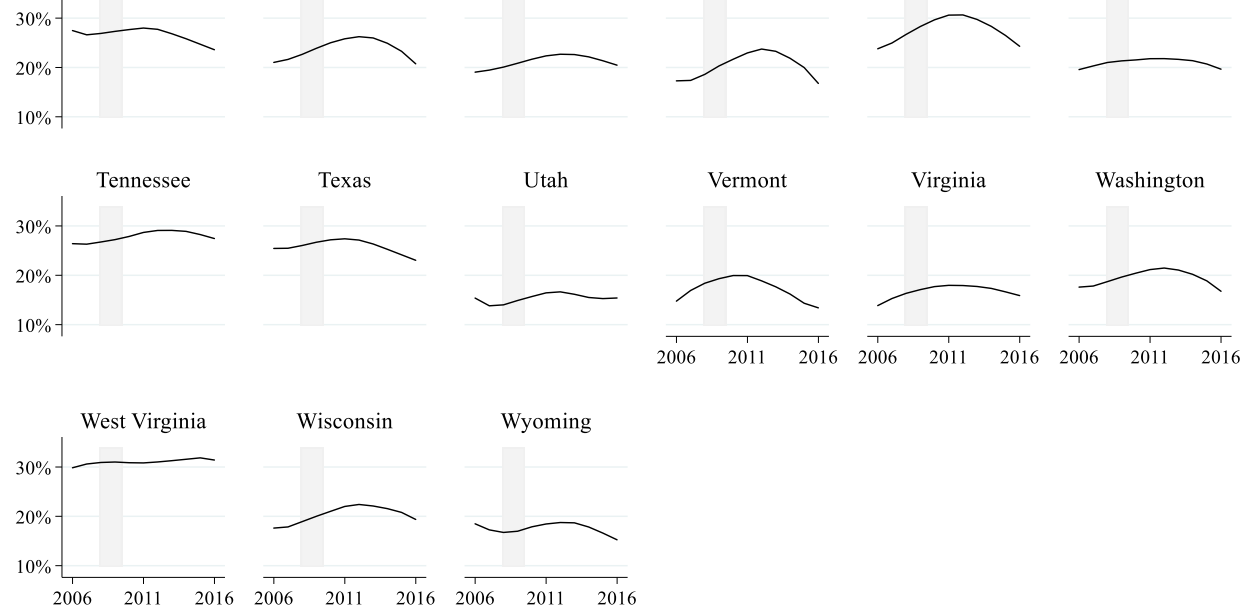

Wisconsin

Wyoming
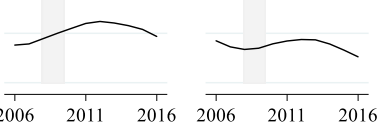

Note: Running-mean smoothing used to highlight longitudinal trends. Shaded areas represent recession period from December 2007 through June 2009.

Source: American Community Survey, 2006 through 2016. 


\section{Head Start Enrollment and Family Poverty Trends}

Table 1 reports the results of four models examining baseline trajectories of family poverty across states (Model 1), main effects of Head Start availability during years of peak economic hardship from 2009 through 2011 (Model 2), whether state trajectories in rates of family poverty were conditional upon Head Start enrollment (Model 3), and a counterfactual model using a sample of families without young children (Model 4). Focusing first on the baseline model, we find that the trend effects represented by the positive coefficient for year and the negative coefficient for year-squared capture an upside-down U-shaped trajectory of growing rates of family poverty through the recession (year, $p<.001$ ) followed by declines in the post-recession years of economic recovery (year-squared, $p<.001$ ). Among covariates, we find that the percentage of eligible families receiving CCDBG subsidies is unrelated to levels of family poverty, while greater state-funded pre-K enrollment is associated with higher levels of state poverty $(p<.01)$. This likely reflects the limited coverage of CCDBG subsidies and the tendency for states with higher rates of poverty to fund pre-K programs. Model 1 also reports that states with high unemployment prior to the recession in 2006 had higher rates of family poverty $(p<$ .05). Severity of the recession, measured through the rise of unemployment between 2007 and 2009, was a non-significant predictor of family poverty after accounting for covariates. Two socio-demographic characteristics, the share of states' population that are foreign-born $(p<.01)$ and college-educated $(p<.001)$, were associated with lower rates of family poverty. These relationships are consistent with research showing that immigration and human capital are a boon to local economies (Agera \& Brückner, 2013; Krueger \& Lindahl, 2001). States’ racial composition and the size of manufacturing sectors were unrelated to rates of family poverty. 


\begin{tabular}{|c|c|c|c|c|c|}
\hline & $\begin{array}{c}\text { Baseline } \\
1\end{array}$ & $\begin{array}{l}\text { Main } \\
\text { Effects } \\
2\end{array}$ & $\begin{array}{l}\text { Trajectories } \\
\text { by Head } \\
\text { Start } \\
\text { Access } \\
3 \\
\end{array}$ & $\begin{array}{l}\text { Counter- } \\
\text { factual } \\
\text { Sample } \\
4\end{array}$ & $\begin{array}{l}\text { Models } 3 \text { and } 4 \\
\text { Coeff. } \\
\text { Significantly } \\
\text { Differ (.05 } \\
\text { level)? }\end{array}$ \\
\hline \multicolumn{6}{|l|}{ Poverty Trajectories } \\
\hline Year (Linear Trend) & $\begin{array}{l}20.56 * * * \\
(1.39)\end{array}$ & $\begin{array}{l}20.56 * * * \\
(1.39)\end{array}$ & $\begin{array}{l}34.40 * * * \\
(3.91)\end{array}$ & $\begin{array}{l}16.37 * * * \\
(2.12)\end{array}$ & Yes \\
\hline Year Squared (Quadratic Trend) & $\begin{array}{l}-1.46^{* * *} \\
(0.11)\end{array}$ & $\begin{array}{l}-1.46^{* * *} \\
(0.11)\end{array}$ & $\begin{array}{l}-2.33 * * * \\
(0.31)\end{array}$ & $\begin{array}{l}-1.08 * * * \\
(0.15)\end{array}$ & Yes \\
\hline $\begin{array}{l}\text { Head Start Access } \\
\text { \% Eligible Enrolled in Head Start During Peak } \\
\text { Recession }\end{array}$ & & $\begin{array}{c}0.01 \\
(0.19)\end{array}$ & $\begin{array}{l}0.80^{* *} \\
(0.25)\end{array}$ & $\begin{array}{l}0.90 * * * \\
(0.21)\end{array}$ & No \\
\hline \multicolumn{6}{|l|}{ Poverty Trajectories by Head Start Access } \\
\hline $\begin{array}{l}\text { Year *\% Eligible Enrolled in Head Start During } \\
\text { Peak Recession }\end{array}$ & & & $\begin{array}{l}-0.27 * * * \\
(0.07)\end{array}$ & $\begin{array}{l}-0.17 * * * \\
(0.04)\end{array}$ & Yes \\
\hline $\begin{array}{l}\text { Year Squared * \% Eligible Enrolled in Head Start } \\
\text { During Peak Recession }\end{array}$ & & & $\begin{array}{l}0.02 * * \\
(0.01)\end{array}$ & $\begin{array}{l}0.01 * * * \\
(0.00)\end{array}$ & No \\
\hline \multicolumn{6}{|l|}{ Controls } \\
\hline \% Eligible Families Receiving CCDBG Subsidies & $\begin{array}{l}-0.48 \\
(1.02)\end{array}$ & $\begin{array}{l}-0.47 \\
(1.02)\end{array}$ & $\begin{array}{l}-0.47 \\
(1.03)\end{array}$ & $\begin{array}{c}0.55 \\
(0.71)\end{array}$ & No \\
\hline$\%$ 3- and 4 Year-Olds in State-Funded Pre-K & $\begin{array}{l}0.95 * * \\
(0.32)\end{array}$ & $\begin{array}{l}0.95 * * \\
(0.32)\end{array}$ & $\begin{array}{l}0.94 * * \\
(0.32)\end{array}$ & $\begin{array}{l}0.76^{* *} \\
(0.24)\end{array}$ & No \\
\hline Baseline Unemployment Rate (2006) & $\begin{array}{l}13.52^{*} \\
(5.63)\end{array}$ & $\begin{array}{l}13.48^{*} \\
(5.65)\end{array}$ & $\begin{array}{l}13.99 * \\
(5.74)\end{array}$ & $\begin{array}{c}3.47 \\
(3.55)\end{array}$ & Yes \\
\hline $\begin{array}{l}\text { Severity of Recession (Change in Unemp. } 2007 \text { to } \\
\text { 2009) }\end{array}$ & $\begin{array}{c}6.54 \\
(4.65)\end{array}$ & $\begin{array}{c}6.58 \\
(4.46)\end{array}$ & $\begin{array}{c}6.61 \\
(4.57)\end{array}$ & $\begin{array}{c}4.95 \\
(3.24)\end{array}$ & No \\
\hline$\%$ Employed in Manufacturing & $\begin{array}{l}-1.00 \\
(2.07)\end{array}$ & $\begin{array}{l}-0.99 \\
(2.12)\end{array}$ & $\begin{array}{l}-1.25 \\
(2.12)\end{array}$ & $\begin{array}{c}1.05 \\
(1.06)\end{array}$ & No \\
\hline$\%$ Foreign Born & $\begin{array}{l}-2.56 * * \\
(0.87)\end{array}$ & $\begin{array}{l}-2.56 * * \\
(0.88)\end{array}$ & $\begin{array}{l}-2.46^{* *} \\
(0.88)\end{array}$ & $\begin{array}{l}-1.76^{* *} \\
(0.63)\end{array}$ & No \\
\hline$\%$ with College Degree & $\begin{array}{l}-4.49 * * * \\
(0.42)\end{array}$ & $\begin{array}{l}-4.49 * * * \\
(0.42)\end{array}$ & $\begin{array}{l}-4.51 * * * \\
(0.42)\end{array}$ & $\begin{array}{l}-1.53^{* *} \\
(0.47)\end{array}$ & Yes \\
\hline$\%$ White & $\begin{array}{l}-0.59 \\
(0.40)\end{array}$ & $\begin{array}{l}-0.59 \\
(0.41)\end{array}$ & $\begin{array}{l}-0.51 \\
(0.39)\end{array}$ & $\begin{array}{l}-0.67 * * \\
(0.22)\end{array}$ & No \\
\hline Constant & $\begin{array}{l}274.23 * * * \\
(43.28)\end{array}$ & $\begin{array}{l}273.86 \text { **** } \\
(43.58)\end{array}$ & $\begin{array}{l}225.32 * * * \\
(43.70)\end{array}$ & $\begin{array}{l}193.33^{* * * *} \\
(32.83)\end{array}$ & \\
\hline \multicolumn{6}{|l|}{ Varying Components (Stand. Deviation) } \\
\hline Year & 5.44 & 5.44 & 2.91 & $2.96 * * *$ & \\
\hline Year Squared & $0.37 * * *$ & $0.37 * * *$ & $0.22 * * *$ & $0.21 * * *$ & \\
\hline Constant & $26.87 *$ & $26.84 *$ & $23.15 * *$ & $20.01 * * *$ & \\
\hline N, State-Years & 561 & 561 & 561 & 561 & \\
\hline
\end{tabular}

Note. Dependent variable is the percent of families in poverty. Standard errors clustered by state, reported in parentheses. All standard errors and coefficients are multiplied by 10 to simplify presentation.

$* \mathrm{p}<.05 . * * \mathrm{p}<.01 . * * * \mathrm{p}<.001$ 
The second model in Table 1 adds the percentage of three- and four-year olds enrolled in Head Start from 2009 through 2011. The main effects presented in Model 2 examine whether Head Start accessibility is associated with overall levels of family poverty, but they do not provide insight on whether Head Start influences change in poverty rates over time (tested in Model 3). The main effects of Head Start accessibility are non-significant. Consistent with previous research (Chaudry et al., 2017), this indicates that Head Start does not scale up to meet changes in the number of eligible families who live in poverty, leaving many families underserved. Yet, the third model in Table 1 shows that Head Start enrollment has significant effects on how poverty rates changed from 2006 through 2016. The negative coefficient for the interaction of Head Start availability and year $(p<.001)$ indicates that states with a higher percentage of eligible children enrolled in Head Start experienced less growth in family poverty during and immediately following the recession, lending support for our first hypothesis. Head Start also moderated year-squared $(p<.01)$, such that states with greater availability of Head Start were more resilient to major fluctuations in rates of family poverty. In other words, states where Head Start was more accessible had flatter curves (smaller recession-related increases in family poverty).

The last model presented in Table 1 uses a counterfactual sample of families without young children as a robustness test of our key findings. Model 4 provides results for the counterfactual sample and the last column in Table 1 reports whether coefficients in Model 3 (focal sample of families with young children) and Model 4 (counterfactual sample of families without young children) are significantly different. The counterfactual model substantiates our key findings. The significant difference between Models 3 and 4 for the interaction of year and Head Start accessibility indicates that Head Start had a larger mitigating effect against poverty 
growth for families with young children than those without young children. Although Head Start slowed poverty growth for all families $(p<.001)$, its effect was significantly stronger for those who stood to benefit directly from the program. These patterns are consistent with previous research showing that social policies to improve parental wellbeing also improve wellbeing among the general population, if only to a smaller extent compared to those with children (Flavin, Pacek, \& Radcliff, 2014; Glass, Simon, \& Andersson, 2016). Our findings suggest that by directly serving vulnerable families to mitigate against poverty, Head Start also enhances states' economic stability more generally.

\section{Visualizing the Effect of Head Start Enrollment on Family Poverty}

Overall, our results reported in Table 1 show that states with higher levels of Head Start enrollment experienced less poverty growth among families with young children during the Great Recession. These trends are illustrated in Figure 4 that shows predicted rates of family poverty from 2006 through 2016 for states where $20 \%, 60 \%$, and $100 \%$ of eligible children were enrolled in Head Start, calculated from Model 3. These percentages capture approximate data points in our sample. For example, Nevada has $22 \%$, Illinois $60 \%$, and North Dakota $100 \%$ of all eligible children enrolled in their Head Start programs. Despite starting out with higher rates of poverty among families with young children in 2006, states with higher Head Start enrollment of eligible children did not experience as rapid an increase in family poverty up to 2012 . In fact, by 2009 there was practically no difference in family poverty rates between high-, medium-, and low- Head Start enrollment states, but by 2012, states with low Head Start enrollment (20\% of eligible enrolled) had family poverty rates nearly one percentage point higher than states where enrollment was at $60 \%$, and nearly two percentage points higher than states with $100 \%$ of eligible children enrolled in Head Start. Although family poverty declined across all states during 
the post-recession period, by 2016 low Head Start enrollment states were still predicted to have higher levels of family poverty than high-enrollment states — a change from 2009 when rates of family poverty did not stratify by Head Start enrollment. This means Head Start enrollment played a key role in states' recoveries post-recession, providing clear evidence for its importance in dealing with the economic fallout resulting from COVID-19 and lending support for our second hypothesis.

Figure 4. Predicted Family Poverty Rates by Head Start Availability

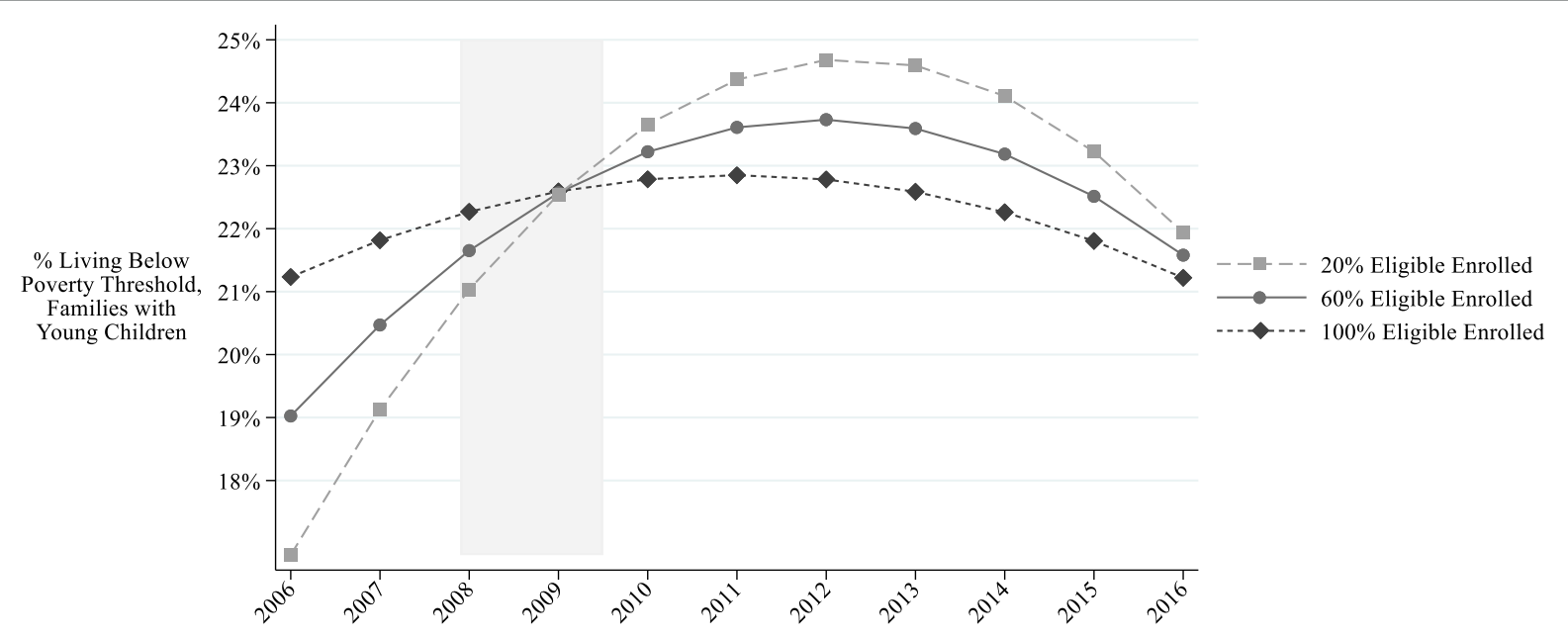

Note: Shaded area represents recession period from December 2007 through June 2009.

Figure 5 plots family poverty rates by year for two illustrative pairs of states to provide comparative cases that highlight the overall trends displayed in Table 1 and Figure 4. State pairs were selected for similarity in initial or post-recession economic conditions, size, and proximity. The first set, Alabama and Mississippi (5a), are bordering states in the South where poverty rates are among the highest in the nation. Both states have low pre-K and CCDBG enrollment, but Head Start enrollment was almost twice as high in Mississippi (90\% of eligible enrolled) as Alabama (47\%) from 2009 to 2011. These differences in Head Start enrollment coincided with 
distinct trends in the family poverty rate between 2006 and 2016. Prior to the recession, the rate of family poverty was about six percentage points higher in Mississippi than Alabama. By the end of the recession, this gap had fallen to 3.5 percentage points, as family poverty in Alabama rose at a faster rate than in Mississippi. Additionally, while rates of family poverty in Mississippi began to decline after 2011, they continued to rise in Alabama for an additional two years until peaking in 2013. Both Alabama and Mississippi had major declines in family poverty after 2013, but the trend was steeper in Mississippi, resulting in these two states having nearly the same family poverty rate by 2016 . In light of the findings from Table 1 , there is strong evidence that convergence in rates of family poverty between Mississippi and Alabama are due in part to the greater availability of Head Start in Mississippi during the years of 2009 through 2011 when many families faced severe economic consequences from the Great Recession. 
Figure 5. Illustrative CASes: Alabama, MississipPi, ARKANSAS, AND OKLAHOMA. 5a. Convergence in Family Poverty Rates.

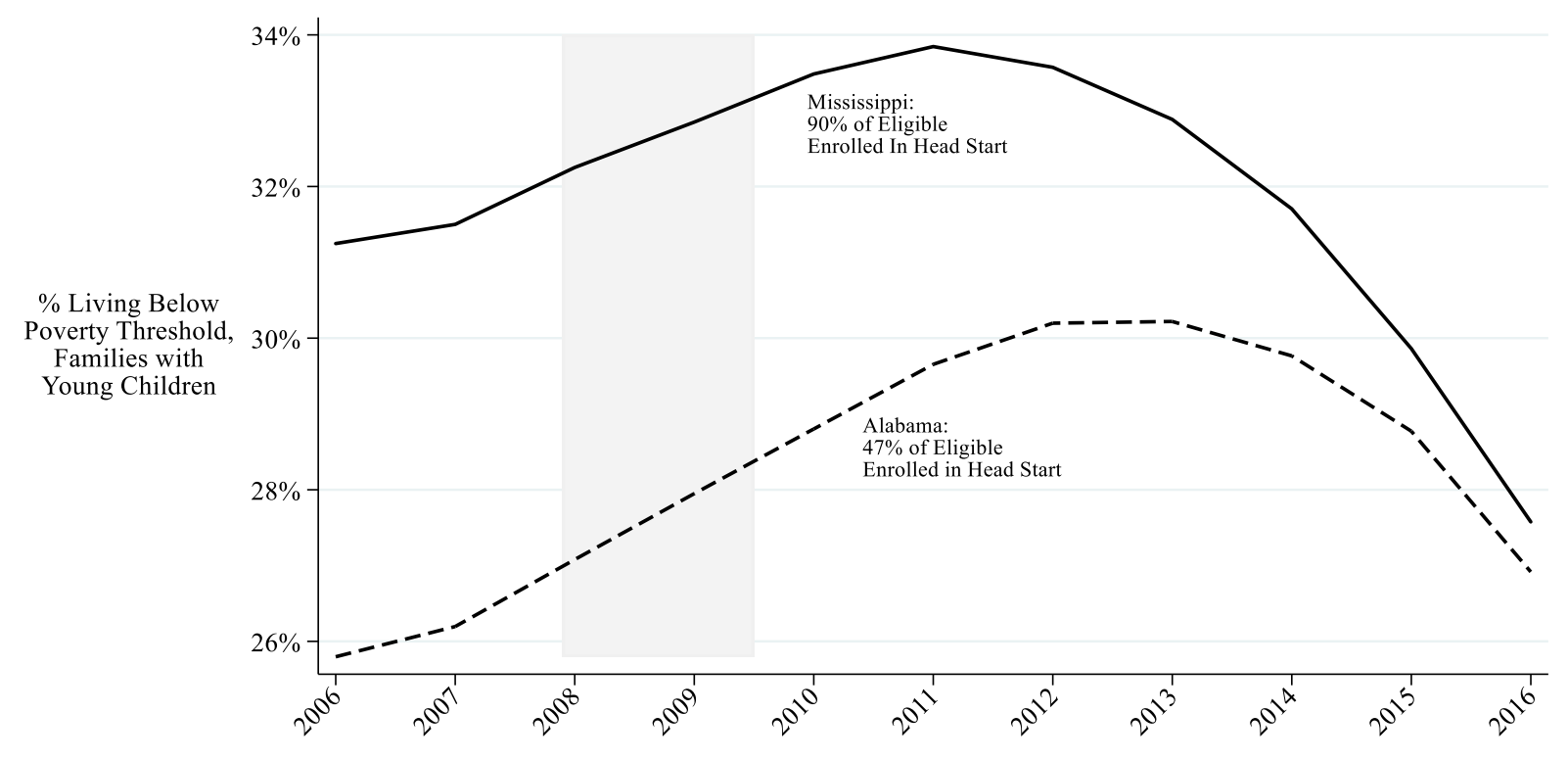

5b. Divergence in Family Poverty Rates.

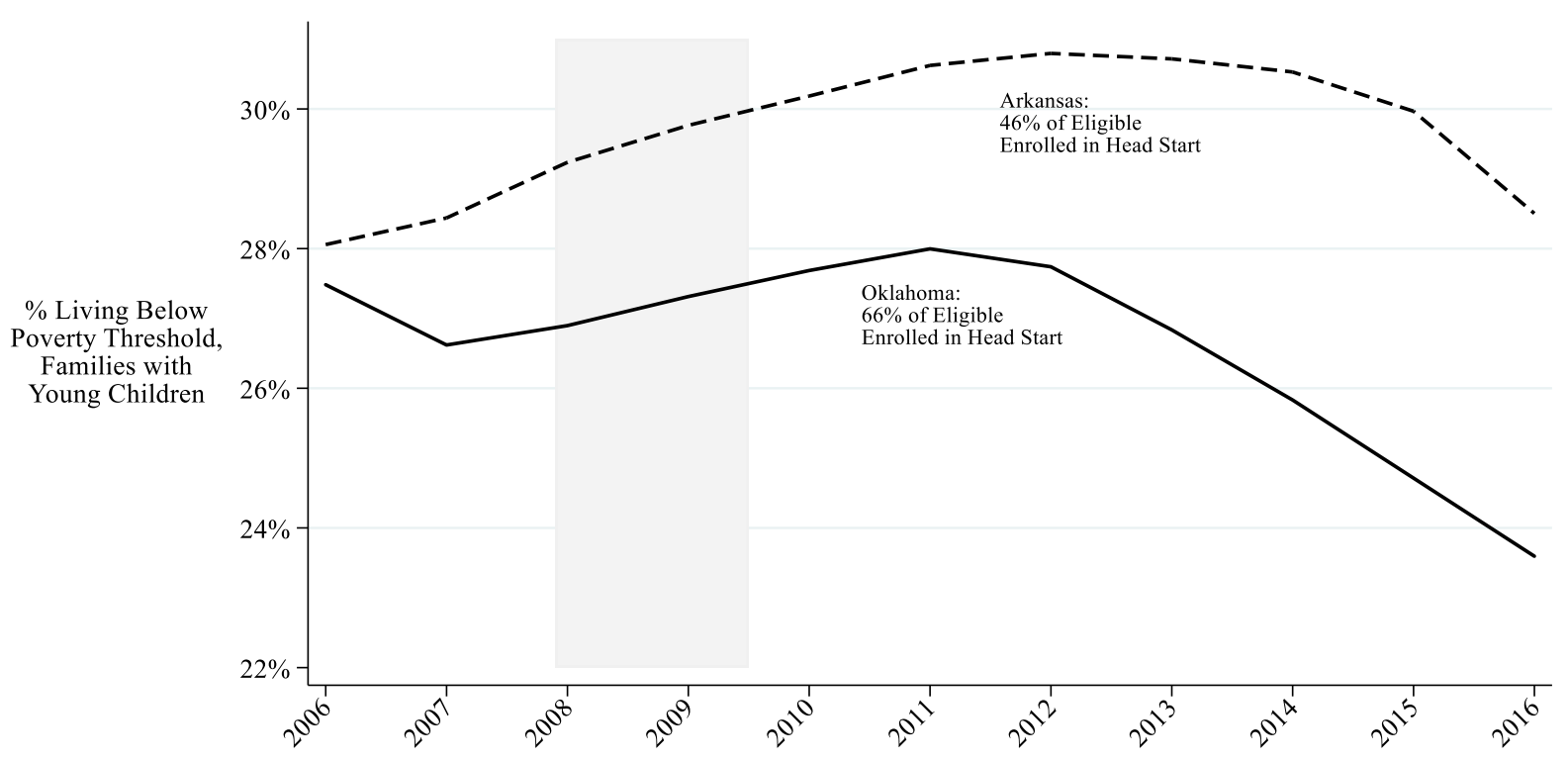

Note: Running-mean smoothing used to highlight longitudinal trends. Shaded area represents recession period from December 2007 through June 2009. Paired states selected for similarity in initial or post-recession economic conditions, size, and proximity. Source: American Community Survey, 2006-2016, and Head Start Program Information Reports, years 2009-2011. 
Whereas Alabama and Mississippi converged in family poverty rates, we observed divergence between Arkansas and Oklahoma (Figure 5b). These bordering states are similar in size and economic conditions. Oklahoma, however, has one of the most comprehensive preschool programs in the nation, with $66 \%$ of eligible children enrolled in Head Start and over $70 \%$ of four-year-olds enrolled in state-funded pre-K programs (pre-K is not offered for threeyear-olds in Oklahoma). Arkansas, in comparison, enrolled $46 \%$ of those eligible in Head Start and around $40 \%$ of four-year-olds and $10 \%$ of three-year-olds in state-funded pre-K. As illustrated in Figure 5b, Oklahoma's robust childcare infrastructure appears to have mitigated against the worst consequences of the Great Recession, which had a greater impact in neighboring Arkansas. Prior to the recession, family poverty rates were similar in Arkansas (28.5\%) and Oklahoma (27.7\%). The recession years contributed to an increase in family poverty in both states, but this growth was much more pronounced in Arkansas, where family poverty rose 2.5 percentage points from 2007 to 2011 , compared to 1.3 percentage points during this same period in Oklahoma. While rates of family poverty began to decline steadily in Oklahoma following 2012, this downward trend did not start until a year later in Arkansas and was less pronounced. As a result, family poverty rates in 2016 were over four percentage points lower in Oklahoma than in Arkansas, despite these states having similar rates in 2006. While Oklahoma's extensive state-funded pre-K programs may have provided further support to families, findings from our growth curve models (Table 1), which controlled for pre-K enrollment, suggest that highly accessible Head Start programs played a key role in supporting families through the Great Recession.

Collectively, our results point to one main conclusion: States with more accessible Head Start programs were better able to weather the economic hardships of the recession and 
experienced a more stable recovery. This result is robust to counterfactual tests and was visibly illustrated in the exemplary cases of Alabama, Mississippi, Arkansas, and Oklahoma. These findings suggest that access to childcare and family support services through Head Start prevented many families from falling into poverty and helped others climb out of it.

\section{Discussion}

Our results provide strong evidence that Head Start should be an integral component of state and federal plans for economic recovery following a recession. States where Head Start was more accessible experienced a smaller increase in family poverty during and after the 2007-2009 economic recession. Applying a capabilities perspective, our findings suggest that economically vulnerable families residing in states with limited openings for Head Start enrollment faced greater challenges and were more likely to fall into poverty. In contrast, families residing in states with greater opportunity to enroll in Head Start received crucial support through periods of economic hardship. Head Start's free childcare and development programs offer a reliable, highquality, and no-cost alternative to expensive market-based childcare. Our findings echo extant qualitative research showing that low-income parents rely heavily on early childhood programs like Head Start. Without them, parents are often forced into unreliable, costly alternatives that can absorb a disproportionate share of wages and increase the likelihood of labor force exit (Newman, 2001; Scott, London, \& Hurts, 2005). In addition, Head Start's family services can provide vital aid during periods of acute crisis as well as longer-term support through adult educational and job training programs. In 2011, Head Start assisted 143,000 families with housing through subsidies or support with utilities and repairs. In that same year, nearly 300,000 Head Start families participated in adult education and training (Office of Head Start 2011). In 
many ways, Head Start provides crucial assistance to families who are the most vulnerable during periods of economic recession.

States fared better during the last recession when Head Start was more widely available. As the U.S. has entered into a COVID-19 economic recession (National Bureau of Economic Research 2020), it is crucial that we learn lessons from the past and implement plans for economic recovery, including stimulus packages that prioritize funding for Head Start and family support more broadly. Such provisions are not only family-friendly policy, but they are also key to economic recovery.

On March 25, 2020, U.S. Congress passed the CARES (Coronavirus Aid, Relief, and Economic Security) Act as the first COVID-19 relief package. Of the $\$ 2$ trillion allocated in the bill, Head Start received $\$ 750$ million to support children whose families have been affected by COVID-19, or less than one-third of $1 \%$ of the total funding allocation. These funds are not sustained through future years and they constitute only a small portion of Head Start's \$10.6 billion annual budget. Consequently, they are unlikely to result in significantly expanded enrollment of Head Start which, our research shows, plays an important role in keeping families out of poverty. One promising sign is that the CARES Act did include $\$ 3.5$ billion for the Child Care and Development Block Grant (CCDBG) to support families' childcare needs. States are given flexibility as to whether these funds are used to keep childcare providers in business after periods of closure or to subsidize childcare costs for families.

The total stimulus funding of $\$ 4.25$ billion for Head Start and CCDBG is vital to maintain the country's childcare infrastructure. But it is not enough. Prior to the pandemic, only $11 \%$ of families who were eligible for childcare subsidies through the CCDBG received this support (U.S. Government Accountability Office, 2016). Although stimulus funds may increase 
the number of subsidies available, demand will almost certainly surge during the recession. Head Start accessibility is comparatively higher than CCDBG subsidy accessibility, but with fewer than half of all eligible children enrolled nationwide (Schmit \& Walker, 2016), demand far exceeded the supply of Head Start spaces prior to the COVID-19 pandemic, and will likely get worse in the immediate future.

Our findings suggest that increased funding to expand Head Start enrollment will be a highly effective use of stimulus funds. There is precedent for expanding federal support for Head Start. At the end of the Great Recession, the American Recovery and Reinvestment Act of 2009 allocated an additional \$2.1 billion to expand Head Start services. Although we cannot disentangle how the additional Head Start spots created by these funds were distributed across states, our findings suggest that states with higher enrollment had fewer families fall into poverty and swifter recoveries. It is likely that the increased federal contribution at that time helped keep many families out of poverty. As we enter the beginning of a COVID-19 related recession, it is crucial that the federal government make similar investments now.

Ensuring that low-income families have accessible childcare and family assistance through Head Start will give them vital support for the difficult economic times ahead. At a minimum, all states need to enroll $100 \%$ of eligible children without further restricting eligibility standards relative to the national guidelines. Studies suggest that it would cost an additional $\$ 14.4$ billion to reach this goal (Barnett \& Friedman-Krauss, 2016). Although this would more than double current Head Start expenditures, this amount is miniscule when compared to the annual increases the federal government has devoted to other types of spending. In addition, the U.S. ranks third to last among OECD nations in funding for early childhood education and care, devoting around $0.4 \%$ of GDP to these programs (OECD, 2019). Sweden, in contrast, spends 
$1.8 \%$ of GDP on early childhood education and care. Spending on these programs exceeds $1.3 \%$ of GDP in France and $0.6 \%$ of GDP in the United Kingdom. Reallocating funds to support early childhood education and care in the U.S. will help mitigate against rising family poverty rates and enhance economic recovery following the recession.

Our findings highlight the benefits of Head Start as a public form of childcare. There are, however, two important limitations to consider. First, because we were interested in how Head Start availability during the height of economic crisis related to changes in family poverty, we used growth curve models that compared shifts in poverty rates between states with varying Head Start enrollment during the peak of the Great Recession. We did not explore whether changes to states' Head Start enrollment from year to year related to concurrent changes in poverty. Future research may investigate these dynamics to uncover whether family poverty rates are responsive to changing levels of Head Start availability across periods taking place outside of economic crises. Second, we focus on the Great Recession because it is a recent economic crisis. Yet, there are important differences between this crisis and the COVID-19 recession. While the Great Recession disproportionately affected those employed in the male-dominated manufacturing sector, present trends indicate that the economic effects of COVID-19 are mostly felt in service industries that are comprised of majority women workers (U.S. Bureau of Labor Statistics, 2012, 2020b). We believe that these differences make the benefits of Head Start even more consequential, as women shoulder a greater share of childcare responsibilities and have more to gain from state childcare and development supports.

\section{Conclusion}

As states and the federal government respond to the COVID-19 economic recession, our findings provide strong evidence that increasing financial investments in Head Start would 
prevent families from falling into poverty and support economic recovery. Drawing lessons from the last recession, we show that states with higher Head Start enrollment during the Great Recession had fewer families in poverty and a more stable recovery. As Congress debates stimulus packages and plans for recovery, evidence-based lessons from the country's past are vital: the federal government should invest in programs proven to support families. By providing childcare, development programs, and comprehensive family services, Head Start fills a crucial need for vulnerable families, particularly during periods of economic hardship.

\section{REFERENCES}

Ager, P., \& Brückner, M. (2013). Cultural Diversity and Economic Growth: Evidence From the U.S. During the Age of Mass Migration. European Economic Review, 64, 76-97.

Barnett, S. W., Carolan, M. E., Fitzgerald, J., \& Squires, J. H. (2011). The State of Preschool 2011. National Institute for Early Education Research.

Barnett, S. W., \& Friedman-Krauss, A. H. (2016). State(s) of Head Start. New Brunswick, NJ: National Institute for Early Education Research.

Chaudry, A., Morrissey, T., Weiland, C., \& Yoshikawa, H. (2017). Cradle to Kindergarten: A New Plan to Combat Inequality. New York: Sage.

Cohen, P., \& Hsu, T. (2020, April 9). "Sudden Black Hole" for the Economy With Millions More Unemployed. The New York Times. https://www.nytimes.com/2020/04/09/business/economy/unemployment-claim-numberscoronavirus.html

Collins, C. (2019). Making Motherhood Work: How Women Manage Careers and Caregiving. Princeton, NJ: Princeton University Press. 
Diversitydatakids.org. (2019). Head Start Capacity: Head Start Participations as Share of Head Start Income-Eligible Children. Heller School for Social Policy and Management at Brandeis University.

Fernandes, N. (2020). Economic Effects of Coronavirus Outbreak (COVID-19) on the World Economy. SSRN Electronic Journal. https://doi.org/10.2139/ssrn.3557504

Flavin, P., Pacek, A. C., \& Radcliff, B. (2014). Assessing the Impact of the Size and Scope of Government on Human Well-Being. Social Forces, 92(4), 1241-1258.

Friedman-Krauss, A. H., Barnett, S. W., Garver, K. A., Hodges, K. S., Weisenfeld, G. G., \& Gardiner, B. A. (n.d.). The State of Preschool 2019. National Institute for Early Education Research.

Glass, J., Simon, R. W., \& Andersson, M. A. (2016). Parenthood and Happiness: Effects of Work-Family Reconciliation Policies in 22 OECD Countries. American Journal of Sociology, 122(3), 886-929. https://doi.org/10.1086/688892

Heggeness, M. L. \& Fields, J. M. (2020, August 18). Working Moms Bear Brunt of Home Schooling While Working During COVID-19. U.S. Census Bureau. Accessed September 4, 2020. https://www.census.gov/library/stories/2020/08/parents-juggle-work-and-childcare-during-pandemic.html?\#.

Hobson, B. (2018). Gendered Dimensions and Capabilities: Opportunities, Dilemmas and Challenges. Critical Sociology, 44(6), 883-898.

Hofferth, S. L. (1994). Who Enrolls in Head Start? A Demographic Analysis of Head StartEligible Children. Early Childhood Research Quarterly, 9, 243-268.

Krueger, A. B., \& Lindahl, M. (2001). Education for Growth: Why and for Whom? Journal of Economic Literature, 39(4), 1101-1136. https://doi.org/10.1257/jel.39.4.1101 
Landivar, L.C. (2017). Mothers at Work: Who Opts Out? Boulder, CO: Lynne Rienner.

Landivar, L.C., Ruppanner, L., Scarborough, W.J., and Collins, C. 2020. Early Signs Indicate that COVID-19 is Exacerbating Gender Inequality in the Labor Force. Socius 6, 1-3.

Mathur, A., \& McCloskey, A. (2014). How to Improve Economic Opportunity for Women. Washington, DC: American Enterprise Institute.

McKibbin, W. J., \& Fernando. (2020). The Global Macroeconomic Impacts of COVID-19: Seven Scenarios. Washington, DC: Brookings.

Misra, J., Moller, S., \& Budig, M. J. (2016). Work-Family Policies and Poverty for Partnered and Single Women in Europe and North America. Gender \& Society, 21(6), 804-827.

National Bureau of Economic Research. (2020). Determination of the February 2020 Peak in US Activity. Accessed September 8, 2020. https://www.nber.org/cycles/june2020.html

Newman, K. S. (2001). Hard Times on 125th Street: Harlem's Poor Confront Welfare Reform. American Anthropologist, 103, 762-778.

Office of Head Start. (2010). Head Start Program Facts: Fiscal Year 2010. https://eclkc.ohs.acf.hhs.gov/about-us/article/head-start-program-facts-fiscal-year-2010

Office of Head Start. (2011). Head Start Program Facts: Fiscal Year 2011. https://eclkc.ohs.acf.hhs.gov/about-us/article/head-start-program-facts-fiscal-year-2011 Office of Head Start. (2019). Sec. 645, Participation in Head Start Programs, Head Start Policy and Regulations. Office of Head Start. https://eclkc.ohs.acf.hhs.gov/policy/head-startact/sec-645-participation-head-start-programs

Office of Head Start. (2020). CARES Act Funding to Support Head Start Programs, Children, and Families. Accessed September 4, 2020. https://eclkc.ohs.acf.hhs.gov/video/cares-actfunding-support-head-start-programs-children-families 
Organizations for Economic Co-operation and Development (OECD). (2019). Public Spending on Family Benefits. (OECD Family Database).

http://www.oecd.org/els/soc/PF1_1_Public_spending_on_family_benefits.pdf.

Raudenbush, S. W., \& Bryk, A. S. (2002). Hierarchical Linear Models: Applications and Data Analysis Methods. New York: Sage.

Ruggles, S., Flood, S. Goeken, R., Grover, J., Meyer, E., Pacas, J., and Sobek, M. IPUMS USA: Version 10.0 [dataset]. Minneapolis, MN: IPUMS, 2020.

Ruppanner, L. (2020). Motherlands: How States in the U.S. Push Mothers Out of Employment. Philadelphia, PA: Temple University Press.

Ruppanner, L., Moller, S., \& Sayer, L. (2019). Expensive Childcare and Short School Days = Lower Maternal Employment and More Time in Childcare? Evidence from the American Time Use Survey. Socius, 5, 2378023119860277.

Scarborough, W. J., Sin, R., \& Risman, B. (2019). Attitudes and the Stalled Gender Revolution: Egalitarianism, Traditionalism, and Ambivalence from 1977 through 2016. Gender \& Society, 33(2), 173-200. https://doi.org/10.1177/0891243218809604

Schmit, S., \& Walker, C. (2016). Disparate Access: Head Start and CCDBG Data by Race and Ethnicity. Washington, D.C.: CLASP.

Scott, E. K., London, A. S., \& Hurst, A. (2005). Instability in Patchworks of Child Care When Moving from Welfare to Work. Journal of Marriage and Family, 67(2), 370-386.

Sen, A. (1993). Capability and Well-Being. In Nussbaum, M., \& Sen, A. (Eds.) The Quality of Life (pp. 30-53). Oxford University Press.

U.S. Bureau of Labor Statistics. (2020a). BLS Data Viewer. Retrieved April 10, 2020, from https://beta.bls.gov/dataViewer/view/timeseries/LNS14000000 
U.S. Bureau of Labor Statistics. (2020b). Employment Situation Summary. The Employment Situation -- April 2020. https://www.bls.gov/news.release/empsit.nr0.htm.

U.S. Bureau of Labor Statistics. (2012). The Recession of 2007-2009 (BLS Spotlight on

Statistics). Washington, D.C.: Bureau of Labor Statistics.

U.S. Census Bureau. (2020). About the American Community Survey. https://www.census.gov/programs-surveys/acs/about.html

U.S. Census Bureau. (2018). Income and Poverty in the U.S., 2018. Washington, D.C.: U.S. Census Bureau.

U.S. Department of Health \& Human Services. (2014). Child Care and Development Fund Statistics. https://www.acf.hhs.gov/occ/resource/ccdf-statistics

U.S. Department of Health \& Human Services. (2019). Characteristics of Families Served by the Child Care and Development Fund (CCDF) Based on Preliminary FY2018 Data. https://www.acf.hhs.gov/occ/resource/characteristics-of-families-served-by-child-careand-development-fund-ccdf

U.S. Department of Health \& Human Services. (2020). Prior HHS Poverty Guidelines and Federal Register References. https://aspe.hhs.gov/prior-hhs-poverty-guidelines-andfederal-register-references

U.S. Government Accountability Office. (2016). Child Care: Access to Subsidies and Strategies to Manage Demand Vary Across States. Government Accountability Office.

Wilmers, N. (2018). Wage Stagnation and Buyer Power: How Buyer-Supplier Relations Affect U.S. Workers' Wages, 1978 to 2014. American Sociological Review, 83(2), 213-242. World Health Organization. (2020). Coronavirus disease 2019 (COVID-19) Situation Report106. World Health Organization. 